\title{
The Impact of Climate Change on Mangrove Forests
}

\author{
Daniel M. Alongi
}

Published online: 30 January 2015

(C) Springer International Publishing AG 2015

\begin{abstract}
Mangrove forests have survived a number of catastrophic climate events since first appearing along the shores of the Tethys Sea during the late Cretaceous-Early Tertiary. The existence of mangrove peat deposits worldwide attests to past episodes of local and regional extinction, primarily in response to abrupt, rapid rises in sea level. Occupying a harsh margin between land and sea, most mangrove plants and associated organisms are predisposed to be either resilient or resistant to most environmental change. Based on the most recent Intergovernmental Panel on Climate Change (IPCC) forecasts, mangrove forests along arid coasts, in subsiding river deltas, and on many islands are predicted to decline in area, structural complexity, and/or in functionality, but mangroves will continue to expand polewards. It is highly likely that they will survive into the foreseeable future as sea level, global temperatures, and atmospheric $\mathrm{CO}_{2}$ concentrations continue to rise.
\end{abstract}

Keywords Climate change - Ecological impacts . Greenhouse $\cdot$ Predictions $\cdot$ Mangroves $\cdot$ Sea level rise . Tropics

\section{Introduction}

Living at the interface between land and sea in the low latitudes, mangroves are sentinels for climate change. Their intertidal environment is physically and geologically dynamic,

This article is part of the Topical Collection on Ecological Impacts of Climate Change

D. M. Alongi $(\bowtie)$

Australian Institute of Marine Science, PMB 3,

Townsville MC, QLD 4810, Australia

e-mail: d.alongi@aims.gov.au and it is primarily these forces, within the confines of changing climatic and environmental conditions, that sculpt mangrove ecosystems over time.

Mangroves exhibit a high degree of ecological stability and community persistence in the face of environmental inconstancy. Their survival is due to a variety of key features that in toto result in ecosystems having properties of both terrestrial and marine biomes plus a few uniquely their own, such as large below-ground storage and transformation rates of carbon and nutrients; simple architecture and self-design; highly efficient but complex biotic controls; species redundancy; and multiple feedbacks which serve to either facilitate and augment recovery from, or resilience to, natural and anthropogenic disturbances $[1,2]$.

Human impacts on mangroves, including climate change, have received much attention of late mainly because mangrove deforestation is occurring at a rate of $1-2 \%$ per year, which implies that most forests will disappear within this century [1]. Despite high rates of destruction, mangroves still play an important role in human sustainability and livelihoods in developing nations where poverty is rife and population growth is high [1]. Mangroves are important nursery grounds and breeding sites for fish, crustaceans, birds, reptiles, mammals, and many other semiterrestrial and estuarine organisms; they help to ameliorate coastal erosion and the impacts of extreme events, such as tsunamis and cyclones; they are a renewable source of wood for fuel and housing, and of food and traditional medicines; and they are biogeochemically important sites of sediment, carbon, nutrient, and contaminant accumulation [1].

The object of this review is to critically assess the impact of climate change on mangrove ecosystems. Sea level rise is the main focus considering their tidal nature, but changes in temperature, salinity, and rainfall patterns, and increases in greenhouse gas concentrations, especially $\mathrm{CO}_{2}$, are also considered. First, however, it is important to consider the evidence for how 
mangroves respond, and have responded, to environmental change; their history of adaptation that will likely offer some insight into their future.

\section{Responses to Sea-Level Change}

Mean sea levels are currently rising as a result of both thermal expansion of ocean water due to increasing temperatures and the melting of polar and land ice [3]. The rise in sea level is not globally uniform as a result of water buildups in some areas, differences in water density due to varying sea temperatures, and the weight of ice sheets. Over geological time, as sea level has waxed and waned in relation to alternating periods of glaciation and warming, mangroves have had to adjust (or not) to rises and falls in sea level.

\section{Surface Elevation Adjustments in Relation to Sea Level}

A number of local and regional short- and long-term processes affect mangrove surface elevation relative to sea level. Eustatic changes in sea level, isostatic changes, subsidence, and changes in the subsurface volume of fluids (e.g., oil, water) are the major long-term processes; short-term processes include accretion of fine sediment particles, litter, and algal mats [4*0], erosion, subsurface expansion due to root growth and filling of soil interstices, and subsidence due to compaction and drainage of interstitial water and microbial decomposition [5-7].

Differences in rates of sediment accretion partly determine how mangroves may change in relation to rates of sea level rise [8•]: (1) if the mangrove forest floor rises at a rate exceeding the local rate of sea level rise, terrestrial plants will invade from landwards as the mangrove forest recedes, but intertidal flats and banks will likely accrete seawards to allow for mangrove colonization and expansion; (2) if the rate of sediment accretion equals the rate of sea level rise, the forest survives and is stable during this period; and (3) if the rate of soil accretion is slower than the rate of sea level rise, the forest drowns seawards but invades land newly flushed by tides. Actual changes may deviate from these scenarios due to local morphological/topographical features (e.g., slope of the forest floor) as well as local events, such as storms [9] and earthquakes [10].

\section{Historical Evidence}

Mangroves descended from terrestrial rainforest plants during the Late Cretaceous-Early Tertiary period [11], first appearing along the shores of the Tethys Sea. Since their evolution and dispersal, mangroves have endured numerous climatic events up to the present day. During the Quaternary, mangroves experienced a sea level that was 120-125 m lower than present at the Last Glacial Maximum, with two periods of very rapid rise ( $>20 \mathrm{~m}$ ) at both 14 and $11 \mathrm{ky} \mathrm{BP}$ as a result of quite abrupt climatic shifts during the transition from the last glacial into the present interglacial [12].

The legacy of past responses to climatic change is reflected in the current distribution of mangroves, but the existence of relic pollen and peat deposits provides abundant evidence of dramatic change over geologic time, especially in relation to late Quaternary sea-level change [13-22]. Analysis of sediment cores for organic geochemical markers, peat deposits, and palynological proxies indicate an overall pattern of paleoecological succession of mangroves in response to changes in sea level.

The geological record indicates that mangroves have kept pace with rising sea level, but in regions experiencing more rapid rise, mangroves have gone locally extinct and in some cases been replaced by freshwater plants. A number of historical patterns have been reconstructed [18-22] all showing significant ecological change depending on the rate of sea-level rise and the influence of other factors, such as rates of subsidence or uplift.

Deep mangrove peat deposits under existing mangroves constitute compelling evidence that over thousands of years, mangroves, such as in the Caribbean [6], have kept pace with sea level rise. However, in other regions, mangrove peat lies below Holocene sediment deposits in shallow coastal and inshore areas [23]. For example, mangrove peat is buried beneath 1-2 $m$ of carbonate deposits within drowned river channels beneath the Great Barrier Reef. These peat deposits are ca. 9.2 cal kp BP (Fig. 1). However, very abrupt changes in the vertical pattern of peat and carbonate deposits suggest that the mangroves drowned fairly quickly (Fig. 1), supporting other evidence of rapid sea-level change about 9-11 kp BP [12]. Buried mangrove peats lie in other coastal waters, such in the Caribbean [13] and the northern Indian Ocean [23]. And while the thicknesses of these peat deposits indicate that mangroves were able to keep pace with the rise in sea level for long time periods, the rate of sea level increased beyond a critical threshold at which mangroves were not able to keep up [8•].

Pollen records reveal a response scenario of oscillations in mangrove succession in synchrony with changing sea level, such as on the island of Borneo [15], on the Caribbean coast of Colombia [16], on the Sunda Shelf in Southeast Asia [17], in East Africa [21] and off the Galápagos [24], and tropical West Africa [14]. Mangrove change also occurs when fluctuating sea-level changes coincide with seismic events, resulting in abrupt changes in mangrove succession and recovery [20, 25•]. This pattern suggests a lowering of surface elevation most probably by seismic activity, but perhaps further affected by hurricanes [26] and peat collapse [8•].

Mangroves have responded not only to sea-level change, but also to changes in long-term shifts in temperature and precipitation. Excellent records of such climatic shifts come 


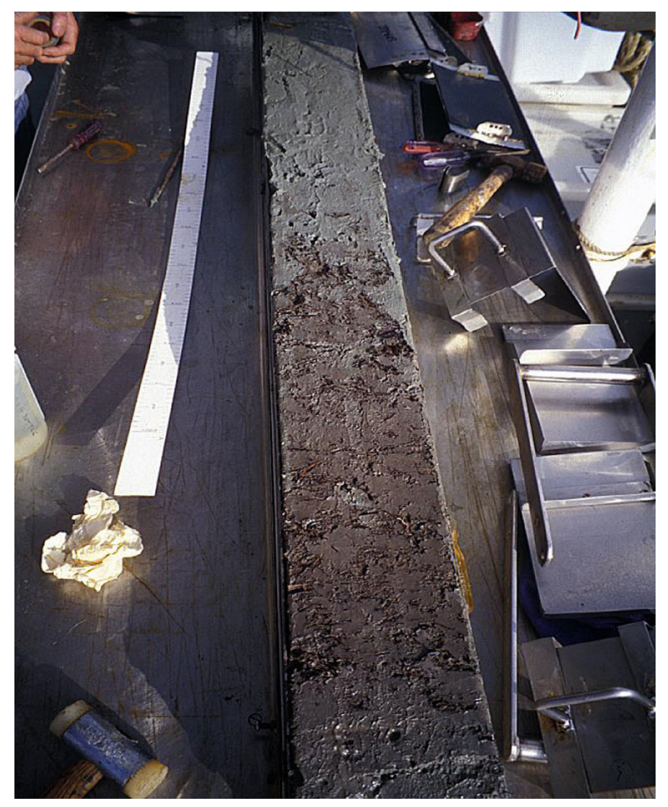

Fig. 1 Photograph of a 1.5-m-long sediment core taken in $22 \mathrm{~m}$ water depth at the Russell Island group (Latitude $17^{\circ} 13.5^{\prime} \mathrm{S}$, Longitude $146^{\circ}$ $05^{\prime} \mathrm{E}$ ) on the Great Barrier Reef Shelf in February 2003. Note the abrupt demarcation halfway up the core between brown mangrove peat and more recent fine carbonate gray sand. Mangrove peat on the shelf is typically aged at 9.3-9.1 ka BP [87]

from Oman on the Arabian Peninsula [19] and along the southwest coast of India [22, 27].

\section{Modern Evidence}

Mangroves continue to respond to changes in sea level [8•]. Modern responses have been well-documented during the past 50 years using a variety of techniques including time series analysis of photos, remote sensing images, and digital terrain models to estimate mangrove expansion or contraction [10, $28,29,30,31 \cdot]$, as well as methods to estimate modern rates of sediment accretion [5-7, 9, 32].

The modern evidence implies that mangrove responses to sea level rise correspond roughly to the patterns of surface elevation change described by McIvor et al. [8•]. For instance, along the Pacific coast of Mexico, rise in sea level accompanied by warm waters of El Niño events have drowned mangroves fringing the shoreline, but has resulted in a net increase in mangroves driven inland [29]. Local variability plays a key role in predicting whether or not mangroves of a specific region will survive or not, as local factors such as geomorphology are important. Also, mangroves occupy a range of tidal settings making it difficult to offer simple prognostications. The situation is similar on the Pacific High Islands of Micronesia [32] where mangrove sedimentation is sufficient to offset elevation losses in some locations, but not in others; low intertidal mangroves are more susceptible to loss of elevation and subsequent flooding than in more landward zones.
Two coastal settings that mangroves readily inhabit but where their future is in doubt are river deltas and low islands. On low islands of the Pacific, such as in Samoa [33], mangroves are migrating landward with rise in sea level, but on many islands, landward migration is obstructed by coastal development. There are many low islands in Micronesia and Melanesia where sea-level rise spells local extinction for mangroves [13]. Worldwide, other low isles are habitats without a future, as are deltas of a number of large tropical rivers [34, 35]. The exemplar is the Sundarbans along the Indian and Bangladesh coast, where subsidence and disappearance of many deltaic islands is ongoing. A time series analysis (1924-2008) indicates that subsidence, a decline in sediment input from the Ganges and other rivers due to damming, and rising sea level, have resulted in a dramatic decline in mangroves on islands in the central and eastern sectors of the Sundarbans $[23,30]$. In other river deltas, sea level rise, storms, and cyclones enhanced subsidence and declines in sediment supply, resulting in a shift of mangroves landwards but with a net contraction [35]. In and proximate to some river deltas where large, migrating mud banks cyclically accrete and erode (e.g., the Amazon), the 18.6-year nodal tidal cycle (tidal amplitude affected by the 18.6-year lunar cycle of ascending and descending nodes of its orbit) is one of the main drivers of shoreline change [36].

Experimental studies have offered some insight into how mangroves respond individually and collectively to sea level rise. A number of studies show species-specific tolerances to prolonged water logging [37-40]. Common mangroves, such as Avicennia marina, exhibit a high degree of tolerance to water logging, but responses are highly variable in relation to length and water depth of immersion, salinity, temperature, and other environmental factors [41, 42].

Species-specific differences in flooding resistance may not be the only biological response by mangroves to sea level rise [43, 44]. A recent review by Yanez-Espinosa and Flores [45] highlights the fact that mangroves exhibit differences in morphology and anatomy in relation to environmental change. For a large number of species, leaf anatomy, vascular vessel densities, diameter, grouping and length, and fiber wall thickness are affected by variations in salinity and flooding. Vessel density, for instance, increases in most species from low to high salinity, from high- to low-flooding level, and from short- to long-flooding period [45]. A few species (e.g., Avicennia germinans, Laguncularia racemosa) have also demonstrated modification to bark anatomy in response to prolonged flooding, typically formation of hypertrophied lenticels, adventitious roots, and increased aerenchyma development in the bark. Over the past 165 years, specific leaf area of A. marina has correlated positively with atmospheric $\mathrm{CO}_{2}$ concentration and latitude, suggesting thicker, heavier leaves in future because of net photosynthetic carbon gain $\left[46^{\bullet}\right]$. 
Mangroves of the future may very well look and function differently, and be denser in terms of number of individuals per unit area $[47,48]$. But, are mangrove forests keeping pace with current rates of sea level rise? A statistical analysis (Fig. 2) of mangrove sedimentation rates ( $\mathrm{mm} \mathrm{year}^{-1}$ ) versus mean sea level rise $\left(\mathrm{mm} \mathrm{year}^{-1}\right)$ suggests that, on average, accretion rates are keeping pace with sea level rise (see regression equation and line, Fig. 2). However, roughly one-half of the data are below the 1:1 relationship (red dotted line) which indicates that these mangroves are not keeping pace; nearly all of these data were derived from mangroves inhabiting low islands and coastal lagoons in the Caribbean and the Pacific, and in subsiding river deltas, such as the Mekong [18] and the Sundarbans [49]. Conversely, the three most rapid accretion rates were from Chinese, Indian, and Brazilian mangroves inhabiting highly populated and impacted catchments. The large scatter of data points underscores how mangroves of disparate coastal settings respond so differently to the same rate of sea-level rise in different parts of the world. These century-scale accretion rates derived from radionuclide distributions (e.g., ${ }^{210} \mathrm{~Pb}$ ) are unlikely to be reliable indicators of the net result of elevation capital, the accretion rate, and water level. Thus, although the linear regression analysis is significant, the reality is that mangroves may respond in complex ways to sea level rise.

\section{Responses to Rising Atmospheric $\mathrm{CO}_{2}$}

Higher $\mathrm{CO}_{2}$ concentrations can enhance the growth of mangroves, but responses are species-specific, with many species'

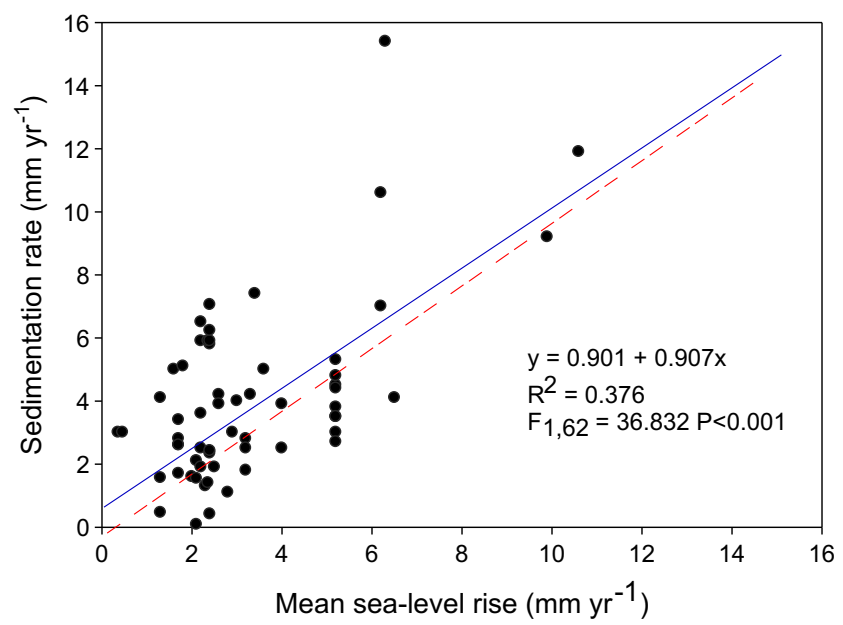

Fig. 2 The relationship between measured rates of mangrove sediment accretion $\left(\mathrm{mm}\right.$ year $\left.^{-1}\right)$ and current rates of mean sea level rise $\left(\mathrm{mm} \mathrm{year}^{-1}\right)$ across the globe. The sea level rise data are from satellite altimetry data available on the website: http://www.nodc.noaa.gov/ General/sealevel.html. Mangrove sedimentation data are from references in Alongi [2] and updated with more recent data [88-100]. Dotted red line delimits a 1:1 relationship and the solid blue line is the linear regression for the untransformed data responses confounded by variations in salinity, nutrient availability, and water-use efficiency [50-55]. The first studies showed that growth of Rhizophora stylosa, Rhizophora apiculata, and Rhizophora mangle was enhanced by increasing $\mathrm{CO}_{2}$ concentrations at low salinity but not at high salinity; all three species showed earlier maturation than control plants [51]. Net primary productivity of $R$. mangle, A. germinans, and Conocarpus erectus was not affected by enhanced $\mathrm{CO}_{2}$ concentrations, but $L$. racemosa showed a decline in productivity; in these experiments, all four species exhibited increases in transpiration efficiency but a decline in stomatal conductance and transpiration with increasing $\mathrm{CO}_{2}$ concentration [52].

These data imply that mangrove responses to increasing atmospheric $\mathrm{CO}_{2}$ will be complex, with some species thriving while others decline or exhibit no or little change. The interactive effects of increased $\mathrm{CO}_{2}$ with salinity and nutrient availability (and temperature, see next section) imply that coastal location may be an important determinant in mangrove response. For instance, species patterns within estuaries may change based on the ability of each species to respond to spatial and temporal differences in salinity, nutrient availability, and other drivers in relation to increasing $\mathrm{CO}_{2}$ levels. This scenario is possible, as indicated by results from modeling exercises. Using the biogeochemical model Biome-BGC and empirical data for A. marina, Kandelia obovata, and Sonneratia apetala in China, a simulation analysis [56 $]$ predicted that increasing atmospheric $\mathrm{CO}_{2}$ concentrations will affect each species differently with only a small $(7 \%)$ increase in net primary productivity (NPP). A doubling of current $\mathrm{CO}_{2}$ concentrations with a $2{ }^{\circ} \mathrm{C}$ increase in temperature would result in a 14-19\% increase in NPP across geographically separate forests and by $12-68 \%$ among monocultural stands of the three species [56•]. The simulation analysis suggests that temperature changes will be a more important driver than increasing $\mathrm{CO}_{2}$ and that different mangrove species will differ in their sensitivity to increases in both drivers. Furthermore, feedbacks may exist between $\mathrm{CO}_{2}$ concentrations, root biomass, and elevation gain [57].

\section{Responses to Increasing Temperatures and Changes} in Precipitation

The physiological response of an organism to increasing temperature follows a sigmoid curve, in which an initial rapid rise in functional processes (e.g., respiration, growth rate) slows, plateaus, and then declines as a critical lethal threshold is reached and then exceeded [58]. Mangrove plants and animals presumably respond so, but the critical temperatures at which functionality plateaus and organisms begin to die are uncertain. Rates of leaf photosynthesis for most species peak at temperatures at or below $30^{\circ} \mathrm{C}$ [58], and leaf $\mathrm{CO}_{2}$ assimilation rates of many species decline, either sharply or gradually, as 
temperature increases from 33 to $35^{\circ} \mathrm{C}$ [58]. Photosynthesis in exposed leaves is often depressed due to photoinhibition; mid-day declines of assimilation have been observed ensuring survival for the photochemical machinery.

What has been the response of mangroves in the field to the ongoing rise in temperature? Temperature increases alone are likely to result in faster growth, reproduction, photosynthesis, and respiration, changes in community composition, diversity, and an expansion of latitudinal limits [59]. Field data indicate that mangroves are indeed currently expanding into higher latitudes in North America [60, 61, 62, 63•], New Zealand [64], Australia [65, 66], southern Africa [67], and southern China [68]. This global expansion polewards is most likely in response to the global rise in sea surface temperatures [69].

As these changes are occurring in the subtropics and tropics, mangrove expansion may also be coupled to changes in precipitation [70]. In an analysis of mangrove latitudinal changes, Quisthoudt et al. [71] found that temperature alone does not delimit the latitudinal range of Rhizophora and Avicennia due partly to large regional differences in monthly temperature change, for instance, warmest month temperatures are higher at the latitudinal limits in the northern, than in the southern, hemisphere. While mangrove expansion and salt marsh contraction are consistent with the poleward increase in temperature $[72 \bullet \bullet]$ and the reduction in the frequency of extreme cold events [73•], other variables such as changes in precipitation cannot be ruled out as co-factors [74].

The expansion of mangroves at the expense of salt marshes suggests that a number of complex ecological interactions are operating during the transition $[63 \bullet, 75,76]$. Proffitt and Travis [76] propose that this migration may be facilitated by increasing propagule abundance from greater reproductive rates and greater genetic variation caused by outcrossing. From field surveys conducted along the Atlantic and Gulf coasts of Florida, they found that reproductive frequencies varied significantly, but increased with latitude and more strongly along the Gulf coast, with a concomitant increase in outcrossing. The migration of mangroves is self-re-enforcing; more colonizers lead to more propagules and outcrossing leads to enhanced genetic variation, thus perpetuating and promoting adaptation to a new environment.

What effect has the rise in temperature had and/or will have on mangrove-associated fauna? No studies have yet demonstrated a change in mangrove fauna associated with global warming, but the results from a few studies [77-79] of macro- and megafauna from adjacent habitats have implications for mangrove organisms. An experimental study [79] has shown that juvenile mullet (Liza vaigiensis) and crescent terapon (Terapon jarbua) frequenting tropical seagrass beds can be acclimated to higher water temperatures, approaching the critical limits for marine vertebrates. Other organisms such as tropical gastropods [78] may respond actively by seeking cooler sites to survive when temperatures exceed $33{ }^{\circ} \mathrm{C}$.
However, tropical organisms are closer to their upper thermal thresholds than boreal and temperate organisms, and are thus more vulnerable to rising temperature $[80,81 \bullet]$.

Mangrove responses to increasing or decreasing precipitation are more straightforward, but such changes are likely to co-occur with rises in sea level, temperature, and atmospheric $\mathrm{CO}_{2}$ concentration. Compared to arid-zone stands, mangrove forests in the wet tropics have greater biomass and productivity, consist of less dense but taller trees, and tend to inhabit finer sediment deposits, but there are no clear species richness or diversity patterns between high and low precipitation areas [82]; low species richness may be attributable to high variability in annual rainfall. But mangroves clearly thrive in wet environments where they can likely deal less stressfully with lower salinity and more available fresh water.

\section{Global Predictions}

What then are we to predict about the global future of mangroves in the face of climate change? There have been a number of general and local prognostications [1, 28, 33, 83], especially in regard to sea level rise $[4 \bullet \bullet, 8 \bullet, 31 \bullet]$, but there have been few attempts at global prediction $[2,84 \bullet \bullet]$. There has been only one sophisticated attempt to forecast mangrove distributions under climate change [84••]. Using several mangrove databases for 30 species across 8 genera, Record et al. [84*0] used the BIOMOD model to make predictions of mangrove species and community distributions under a range of sea level rise and global climate scenarios up to the year 2080 . The model runs came up with two clear predictions: (1) some species will continue migrating polewards but experience a decline in available space; and (2) Central America and the Caribbean will lose more species than other parts of the world. The latter prediction is in agreement with the work of Polidoro et al. [85••] in which extinction risk of threatened species was assessed and the main geographical area of concern was found to be the Atlantic and Pacific coasts of Central America.

The recent climatological forecasts by the Intergovernmental Panel on Climate Change (IPCC) [3, 86] for until the end of this century predict that globally (1) sea surface temperatures will rise by $1-3{ }^{\circ} \mathrm{C}$, (2) oceanic $\mathrm{pH}$ will decline by $0.07-0.31$, and (3) mean atmospheric $\mathrm{CO}_{2}$ concentrations will increase to $441 \mathrm{ppm}$ (from $391 \mathrm{ppm}$ in 2011). Regional differences (Table 1) will occur for some parameters such as (1) sea level, which will continue to rise globally at an average rate between 1.8 and $2.4 \mathrm{~mm} \mathrm{year}^{-1}$; (2) precipitation will increase and decrease in some regions such that arid areas will become more arid and the wet tropics will become wetter; and (3) salinity will change in tandem with changes in precipitation. Considering these climatic predictions and the known and likely responses of mangroves to changes in temperature, salinity, sea level rise, etc., I offer some predictions (Fig. 3): 
Table 1 IPCC projected regional changes in salinity, precipitation, and sea level rise for 2081-2100 (relative to the 1986-2005 reference period)

\begin{tabular}{llll}
\hline Region & Salinity & Precipitation ${ }^{\mathrm{b}}$ & Sea level rise $^{\mathrm{c}}$ \\
\hline N South America & 0 to $0.5 \uparrow$ & -10 to $40 \% \downarrow$ & $0.22-0.24 \mathrm{~m}$ \\
E South America & 0 to $0.5 \uparrow$ & 0 to $+10 \% \uparrow$ & $0.18-0.20 \mathrm{~m}$ \\
Caribbean \& W Central America & 0.5 to $1.0 \uparrow$ & -20 to $10 \% \downarrow$ & $0.18-0.20 \mathrm{~m}$ \\
Central West Africa & 0 to $1.5 \downarrow$ & 10 to $20 \% \uparrow$ & $0.20-0.24 \mathrm{~m}$ \\
Central East Africa & 0 to $2.0 \downarrow$ & 10 to $50 \% \uparrow$ & -10 to $10 \% \leftrightarrow$ \\
Red Sea/Arabian Peninsula & No change & -40 to $10 \% \downarrow$ & $0.20-0.24 \mathrm{~m}$ \\
South Asia & 0 to $0.5 \uparrow$ & 0 to $20 \% \uparrow$ & $0.22-0.24 \mathrm{~m}$ \\
SE Asia & 0 to $1.0 \downarrow$ & 0 to $10 \% \downarrow$ & $0.18-0.24 \mathrm{~m}$ \\
N Australia & No change & -10 to $0 \% \downarrow$ & $0.18-0.20 \mathrm{~m}$ \\
E Australia & No change & 0 to $10 \% \uparrow$ & $0.18-0.20 \mathrm{~m}$ \\
Oceania & No change & $0.18-0.20 \mathrm{~m}$ \\
\hline
\end{tabular}

${ }^{a}$ The range of projected sea surface salinity changes for 2081-2100 relative to the 1986-2005 reference period. Data from Collins et al. [86]

${ }^{b}$ The range of projected changes in December to February precipitation for 2081-2100 relative to 1986-2005. Data from Collins et al. [86]

${ }^{\mathrm{c}}$ The range of ensemble mean projections of the time-averaged dynamic and steric sea level changes for the period 2081-2100 relative to 1986-2005. Data from Church et al. [3]

- Prediction 1 (red lines): Mangrove forests along arid coasts will decline as salinities increase, freshwater becomes most scarce, and critical temperature thresholds are reached more frequently (e.g., NW Australia, Pakistan, Arabian Peninsula, both Mexico coasts).

- Prediction 2 (orange lines): Mangrove forests will decline as sediment yield declines, salinity increases, and sea level rises in tropical river deltas subject to subsidence intervals (e.g., the Sundarbans; the Mekong, Zaire, Fly Rivers).

- Prediction 3 (purple lines): Mangrove forests will decline as sea level rises and there is little or no upland space to colonize (e.g., low islands of Oceania, many Caribbean islands).

- Prediction 4 (blue lines): Mangroves forests will continue to expand their latitudinal range as temperature and atmospheric $\mathrm{CO}_{2}$ concentrations increase (New Zealand, USA, Australia, China).

Some assumptions were made in making these predictions: (1) the predicted contraction or expansion of mangroves assumes complex (but difficult to forecast) changes in floral and faunal species composition, morphology, biodiversity,

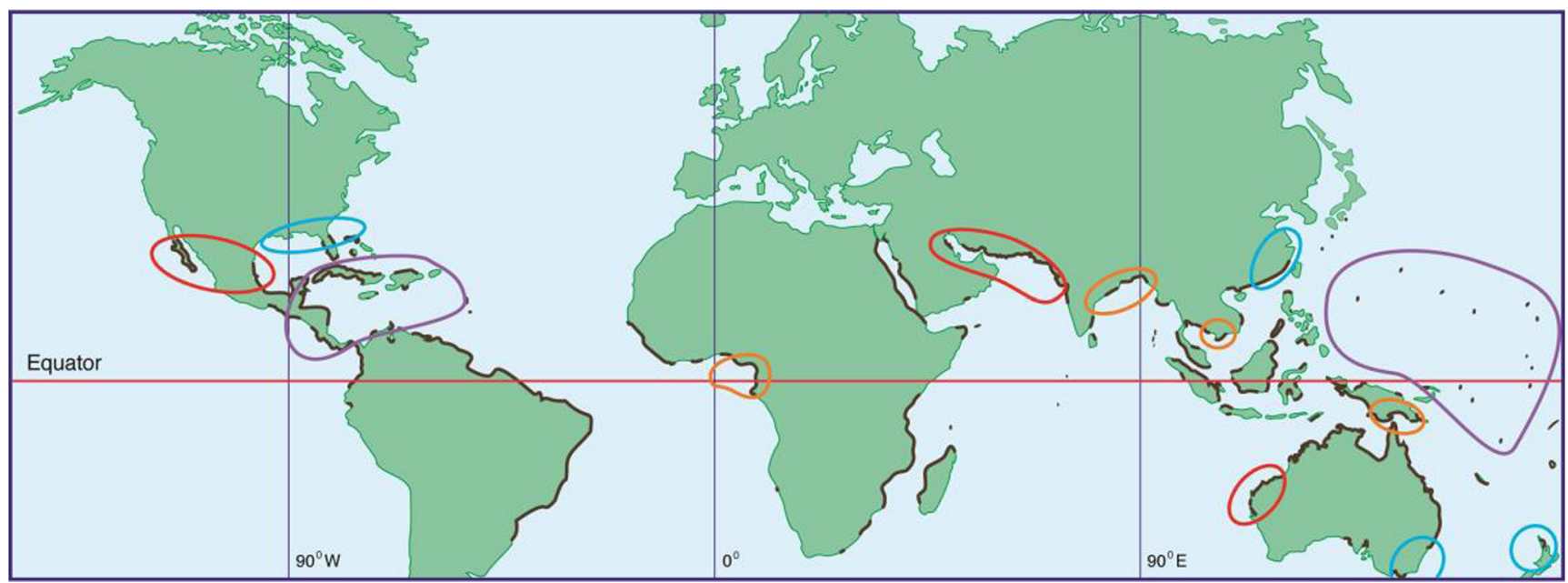

Fig 3 Predictions of climate change impacts on the world's mangrove forests, based on IPCC forecasts for climate to the end of the twenty-first century. Prediction 1 (red lines) decline as salinities increase, freshwater becomes most scarce, and critical temperature thresholds are reached more frequently (e.g., NW Australia, Pakistan, Arabian Peninsula, both Mexico coasts); prediction 2 (orange lines): mangrove forests will decline as sediment yield declines, salinity increases, and sea level rises in tropical river deltas undergoing subsidence (e.g., the Sundarbans; the
Mekong, Zaire, Fly Rivers); prediction 3 (purple lines): mangrove forests will decline as sea level rises, and there is little or no upland space to colonize (e.g., Oceania, many Caribbean islands); prediction 4 (blue lines): mangroves forests will continue to expand their latitudinal range as temperature and atmospheric $\mathrm{CO}_{2}$ concentrations increase $(\mathrm{New}$ Zealand, USA, Australia, China). Mangroves in some geographical regions that are currently in decline due to deforestation (e.g., Central and South America, Asia) are not circled on the map 
biomass, physiology, growth, and productivity; (2) the decline on ocean $\mathrm{pH}$ will have little or no impact on mangroves considering that they are subject to diurnal changes in tidal water and soil $\mathrm{pH}[1]$; (3) mangrove functionality (growth, respiration, productivity, etc.) will increase in line with increases in temperature, precipitation, and atmospheric $\mathrm{CO}_{2}$ concentrations up to critical physiological thresholds, but only when other environmental conditions are favorable as suggested from the complex interactive effects observed in many growth experiments discussed in the previous section; and (4) most mangroves will survive the predicted global rate of sea level rise unless other factors, such as subsidence, significantly impact overall surface elevation.

\section{Conclusions}

Mangroves will survive into the future but there have already been, and will continue to be, more negative than positive impacts due to climate change. Mangroves are expanding their latitudinal range as global temperatures continue to rise. Mangrove forests will either experience little change or some positive impact in areas where precipitation is forecast to increase, such as in SE Asia and along the western and central coasts of Africa. But mangrove forests will decline as aridity increases in parts of the Caribbean, Central and South America, and South Asia. The greatest current threat to mangrove survival, however, is deforestation and such continuing losses must be considered in tandem with the impact of climate change.

Conflict of Interest The author states that he has no financial or personal relationships with any third party whose interests could be positively or negatively influenced by the article's content.

\section{References}

Papers of particular interest, published recently, have been highlighted as:

- Of importance

-• Of major importance

1. Alongi DM. Present state and future of the world's mangrove forests. Environ Conserv. 2002;29:331-49. doi:10.1017/ S0376892902000231.

2. Alongi DM. Mangrove forests: resilience, protection from tsunamis, and responses to global climate change. Estuar Coast Shelf Sci. 2008;76:1-13. doi:10.1016/j.ecss.2007.08.024.

3. Church JA, Clark PU, Cazenave A, Gregory JM, Jevrejeva S, Levermann A, Merrifield MA, Milne GA, Nerem RS, Nunn PD, Payne AJ, Pfeffer WT, Stammer D, Unnikrishnam AS (2013) Sea level change. In: Stocker TF, Qin D, Plattner G-K, Tignor M, Allen SK, Boschung J, Nauels A, Xia Y, Bex V, Midgley PM (eds.) Climate change 2013: the physical basis, contribution of working group I to the fifth assessment report of the Intergovernmental panel on climate change. Cambridge, pp $1029-1136$.

4.• Krauss KW, McKee KL, Lovelock CE, Cahoon DR, Saintilan N, Reef R, et al. How mangrove forests adjust to rising sea level. New Phytol. 2013. doi:10.1111/nph.12605. An excellent overview of mangrove responses to sea-level rise as seen from a biophysical perspective. Great emphasis on the ability of mangroves to increase their own elevation by a number of biotic mechanisms.

5. McKee KL. Biophysical controls on accretion and elevation change in Caribbean mangrove ecosystems. Estuar Coast Shelf Sci. 2011;91:475-83. doi:10.1016/j.ecss.2010.05.001.

6. McKee KL, Cahoon DR, Feller IC. Caribbean mangroves adjust to rising sea level through biotic controls on change in soil elevation. Glob Ecol Biogeogr. 2007;16:545-56. doi:10.1111/j.14668238.2007.00317.x.

7. Lovelock CE, Bennion V, Grinham A, Cahoon DR. The role of surface and subsurface processes in keeping pace with sea level rise in intertidal wetlands of Moreton Bay, Queensland, Australia. Ecosystems. 2011;14:743-57. doi:10.1007/s10021-011-9443-9.

8. McIvor A, Spencer T, Möller, Spalding M (2013) The response of mangrove soil surface elevation to sea level rise. Natural Coastal Protection Series: Report 3. Cambridge Coastal Research Unit Working Paper 42. The Nature Conservancy and Wetlands International. An exhaustive review of the entire mangrove-sea level rise issue. The various scenarios are examined and explained with great clarity. http://coastalresilience.org/science/mangroves/ surface-elevation-and-sea-level-rise

9. Smoak JM, Breithaupt JL, Smith III TJ, Sanders CJ. Sediment accretion and organic carbon burial relative to sea-level rise and storm events in two mangrove forests in Everglades National Park. Catena. 2013;104:58-66. doi:10.1016/j.catena.2012.10.009.

10. Sanders CJ, Eyre BD, Santos IR, Machado W, Luiz-Silva W, Smoak JM, et al. Elevated rates of organic carbon, nitrogen, and phosphorus accumulation in a highly impacted mangrove wetland. Geophys Res Lett. 2014;41:2475-80. doi:10.1002/ 2014GL059789.

11. Ricklefs RE, Schwarzbach AE, Renner SS. Rate of lineage origin explains the diversity anomaly in the world's mangrove vegetation. Am Nat. 2006;168:805-10. doi:10.1086/508711.

12. Endfield GH, Marks RB. Historical environmental change in the tropics. In: Metcalfe SE, Nash DJ, editors. Quaternary environmental changes in the tropics. Chicester: Wiley; 2012. p. 360-91. doi:10.1002/9781118336311.ch10.

13. Ellison JC. Long-term retrospection on mangrove development using sediment cores and pollen analysis: a review. Aquat Bot. 2008;89:93-104. doi:10.1016/j.aquabot.2008.02.007.

14. Kim J-H, Dupont L, Behling H, Versteegh GJM. Impacts of rapid sea-level rise on mangrove deposit erosion: application of teraxeroland Rhizophora records. J Quatern Sci. 2005;20:221-5. doi:10.1002/jqs.904.

15. Yulianto E, Rahardjo AT, Noeradi D, Siregar DA, Hirakawa K. A Holocene pollen record of vegetation and coastal environmental changes in the coastal swamp forest at Batulicin, South Kalimantan, Indonesia. J Asian Earth Sci. 2005;25:1-8. doi:10. 1016/j.jseaes.2004.01.005.

16. Urrego LE, Correa-Metrio A, González C, Castaño AR, Yokoyama Y. Contrasting responses of two Caribbean mangroves to sea-level rise in the Guajira Peninsula (Colombian Caribbean). Paleogeogr Paleoclim Paleoecol. 2013;370:92-102.

17. Hanebuth TJJ, Voris HK, Yokoyama Y, Saito Y, Okuno J. Formation and fate of sedimentary depocentres on Southeast Asia's Sunda Shelf over the past sea-level cycle and biogeographic implications. Earth-Sci Rev. 2011;104:92-110. doi:10.1016/j. earscirev.2010.09.006. 
18. Li Z, Saito Y, Mao L, Tamura T, Li Z, Song B, et al. Mid-Holocene mangrove succession and its response to sea-level change in the upper Mekong River delta, Cambodia. Quatern Res. 2012;78: 386-99. doi:10.1016/j.yqres.2012.07.001.

19. Berger JF, Charpentier V, Crassard R, Martin C, Davtian G, López-Sáez JA. The dynamics of mangrove ecosystems, changes in sea level and the strategies of Neolithic settlements along the coast of Oman (6000-3000 cal. BC). J Archaeol Sci. 2013;40: 3087-104. doi:10.1016/j.jas.2013.03.004.

20. McCloskey TA, Liu K-B. Sedimentary history of mangrove cays in Turneffe Islands, Belize: evidence for sudden environmental reversals. J Coast Res. 2013;29:971-83. doi:10.2112/ JCOASTRES-D-12-00156.1.

21. Punwong P, Marchant R, Selby K. Holocene mangrove dynamics in Makoba Bay, Zanzibar. Paleogeogr Plaeoclimat Paleoecol. 2013;379-380:54-67. doi:10.1016/j.palaeo.2013.04.004.

22. Limaye RB, Kumaran KPN, Padmalal D. Mangrove habitat dynamics in response to Holocene sea level and climate changes along southwest coast of India. Quatern Int. 2014;325:116-25. doi:10.1016/j.quaint.2013.12.031.

23. Rashid T. Holocene sea-level scenarios in Bangladesh. Singapore: Springer Briefs in Oceanography; 2014. doi:10.1007/978-9814560-99-3

24. Seddon AWR, Froyd CA, Leng MJ, Milne G, Willis KJ. Ecosystem resilience and threshold response in the Galápagos coastal zone. PLoS ONE. 2011;6:e22376. doi:10.1371/journal. pone.0022376.

25. França MC, Francisquini MI, Cohen MCL, Pessenda LCR. Interproxy evidence for the development of the Amazonian mangroves during the Holocene. Veget Hist Archaeobot. 2014;23:527-42. doi:10.1007/s00334-013-0420-4. A fine study of the highly complex episodes of mangrove expansion and contraction in proximity to, in this case, the exemplar of large tropical rivers.

26. Castañeda-Moya E, Twilley RR, Rivera-Monroy VH, Zhang K, Davis III SE, Ross M. Sediment and nutrient deposition associated with Hurricane Wilma in mangroves of the Florida coastal Everglades. Estuar Coast Shelf Sci. 2010;33:45-58. doi:10.1007/ s12237-009-9242-0.

27. Kumaran KPN, Limaye RB, Padmalal D. Mangrove responses to climate change along the southwestern coast of India during the Holocene: evidence from palynology and geochronology. In: Sundaresan J, Sreekesh S, Ramanathan AL, Sonnenschein L, Boojh R, editors. Climate change and island and coastal vulnerability. Dordrecht: Springer; 2013. p. 217-38. doi:10.1007/978-94007-6016-5 15.

28. Gilman EL, Ellison J, Coleman R. Assessment of mangrove response to projected relative sea-level rise and recent historical reconstruction of shoreline position. Environ Monit Assess. 2007;124:105-30. doi:10.1007/s10661-006-9212-y.

29. López-Medellin X, Ezcurra E, González-Abraham C, Hak J, Santiago LS, Sickman JO. Oceanographic anomalies and sealevel rise drive mangroves inland in the pacific coast of Mexico. J Veg Sci. 2011;22:143-51. doi:10.1111/j.1654-1103.2010. 01232.x.

30. Rahu A, Das S, Banerjee K, Mitra A. Climate change impacts on Indian Sunderbans: a time series analysis (1924-2008). Biodivers Conserv. 2012;21:1289-307. doi:10.1007/s10531-01200260-z.

31. Di Nitto D, Neukermans G, Koedam N, Defever H, Pattyn F, Kairo JG, et al. Mangroves facing climate change: landward migration potential in response to projected scenarios of sea level rise. Biogeosci. 2014;11:857-71. doi:10.5194/bg-11-857-2014. A thorough modelling study of nearly all of the possible scenarios of mangrove response to sea level rise.

32. Krauss KW, Cahoon DR, Allen JA, Ewel KC, Lynch JC, Cormier N. Surface elevation change and susceptibility of different mangrove zones to sea-level rise on pacific high islands of Micronesia. Ecosystems. 2010;13:129-43. doi:10.1007/s10021009-9307-8.

33. Gilman EL, Ellison J, Duke NC, Field C. Threats to mangroves from climate change and adaptation options: a review. Aquat Bot. 2008;89:237-50. doi:10.1016/j.aquabot.2007.12.009.

34. Restrepo JD, Kettner A. Human induced discharge diversion in a tropical delta and its environmental implications: the Patía River, Colombia. J Hydrol. 2012;424-425:124-42. doi:10.1016/j. jhydrol.2011.12.037.

35. Shearman P, Bryan J, Walsh JP. Trends in deltaic change over three decades in the Asia-pacific region. J Coast Res. 2013;29: 169-1183. doi:10.2112/JCOASTRES-D-12-00120.1.

36. Gratiot N, Anthony EJ, Gardel A, Gaucherel C, Proisy C, Wells JT. Significant contribution of the 18.6 year tidal cycle to regional coastal changes. Nat Geosci. 2008;1:169-72. doi:10.1038/ ngeo 127.

37. Ye Y, Tam NFY, Wong YSLCY. Growth and physiological responses of two mangrove species (Bruguiera gymnorrhiza and Kandelia candel) to waterlogging. Environ Exp Bot. 2003;49: 209-21. doi:10.1016/S0098-8472(02)00071-0.

38. Ye Y, Tam NFY, Wong YSLCY. Does sea level rise influence propagule establishment, early growth and physiology of Kandelia candel and Bruguiera gymnorrhiza? J Exp Mar Biol Ecol. 2004;306:197-215. doi:10.1016/j.jembe.2004.01.011.

39. Ye Y, Gu YT, Gao HY, Lu CY. Combined effects of simulated tidal sea-level rise and salinity on seedlings of a mangrove species, Kandelia candel (L.) Cruce. Hydrobiologia. 2010;641:287-300. doi:10.1007/s10750-010-0099-9.

40. Cardona-Olarte P, Twilley RR, Krauss KW, Rivera-Monroy V. Responses of neotropical mangrove seedlings grown in monoculture and mixed culture under treatments of hydroperiod and salinity. Hydrobiologia. 2006;569:325-91. doi:10.1007/s10750-0060140 .

41. Lu WZ, Chen LZ, Wang WQ, Tam NFY, Lin GH. Effects of sea level rise on mangrove Avicennia population growth, colonization and establishment: evidence from a field survey and greenhouse manipulation experiment. Acta Oecol. 2013;49:83-91. doi:10. 1016/j.actao.2013.03.009.

42. Mangora MM, Mtolera MSP, Björk M. Photosynthetic responses to submergence in mangrove seedlings. Mar Freshw Res. 2014;65:497-504. doi:10.1071/MF13167.

43. Ellison AM, Farnsworth EJ. Simulated sea level change alters anatomy, physiology, growth and reproduction of red mangrove (Rhizophora mangle L.). Oecologia. 1997;112:435-46. doi:10. 1007/s004420050330.

44. Wang W, Xiao Y, Chen L, Lin P. Leaf anatomical responses to periodical waterlogging in simulated semidiurnal tides in mangrove Bruguiera gymnorrhiza seedlings. Aquat Bot. 2007;86: 223-8. doi:10.1016/j.aquabot.2006.10.003.

45. Yáñez-Espinosa L, Flores J (2011) A review of sea-level rise effect on mangrove forest species: anatomical and morphological modifications. In: Casalengo (ed), Global warming impacts-case studies on the economy, human health, and on urban and natural environments. InTech, pp 253-276. doi:10.5772/1935

46. Reef R, Lovelock CE. Historical analysis of mangrove leaf traits throughout the 19th and 20th centuries reveals differential responses to increases in atmospheric $\mathrm{CO}_{2}$. Glob Ecol Biogeogr. 2014. doi:10.1111/geb.12211. A fascinating examination of how the leaves of common mangrove species have changed over more than a century. Rare in that actual specimens were studied.

47. Huxham M, Kumara MP, Jayatissa LP, Krauss KW, Kairo J, Lang' at $\mathrm{J}$, et al. Intra- and interspecific facilitation in mangroves may increase resilience to climate change threats. Phil Trans R Soc B. 2010;365:2127-35. doi:10.1098/rstb.2010.0094. 
48. Kumara MP, Jayatissa LP, Krauss KW, Phillips DH, Huxham M. High mangrove density enhances surface accretion, surface elevation change, and tree survival in coastal areas susceptible to sealevel rise. Oecologia. 2010;164:545-53. doi:10.1007/s00442010-1705-2.

49. Hanebuth TJJ, Kudrass HR, Linstädter IB, Zander AM. Rapid coastal subsidence in the central Ganges-Brahmaputra Delta (Bangladesh) since the 17th century deduced from submerged salt-producing kilns. Geology. 2013;41:987-90. doi:10.1130/ G34646.1.

50. Farnsworth EJ, Ellison AM, Gong WK. Elevated $\mathrm{CO}_{2}$ alters anatomy, physiology, growth, and reproduction of red mangrove (Rhizophora mangle L.). Oecologia. 1996;108:599-609. doi:10. 1007/BF00329032.

51. Ball MC, Cochrane MJ, Rawson HM. Growth and water use of the mangroves Rhizophora apiculata and R. stylosa in response to salinity and humidity under ambient and elevated concentrations of atmospheric $\mathrm{CO}_{2}$. Plant Cell Environ. 1997;20:1158-66. doi: 10.1046/j.1365-3040.1997.d01.44.x.

52. Snedaker SC, Araújo RJ. Stomatal conductance and gas exchange in four species of Caribbean mangroves exposed to ambient and increased $\mathrm{CO}_{2}$. Mar Freshw Res. 1998;49:325-7. doi:10.1071/ MF98001.

53. Cherry JA, McKee KL, Grace JB. Elevated $\mathrm{CO}_{2}$ enhances biological contributions to elevation change in coastal wetlands by offsetting stressors associated with sea-level rise. J Ecol. 2009;97:6777. doi:10.1111/j.1365-2745.2008.01449.x.

54. McKee KL, Rooth JE. Where temperate meets tropical: multifactorial effects of elevated $\mathrm{CO}_{2}$, nitrogen enrichment, and competition on a mangrove-salt marsh community. Global Change Biol. 2008;14:971-84. doi:10.1111/j.1365-2486.2008.01547.x.

55. McKee KL, Rogers K, Saintilan N. Response of salt marsh and mangrove wetlands to changes in atmospheric $\mathrm{CO}_{2}$, climate, and sea level. In: Middleton BA, editor. Global change and the function and distribution of wetlands. Dordrecht: Springer; 2012. p. 63-96. doi:10.1007/978-94-007-4494-3 2.

$56 . •$ Luo Z, Sun OJ, Wang E, Ren H, Xu H. Modeling productivity in mangrove forests as impacted by effective soil water availability and its sensitivity to climate change using Biome-BGC. Ecosystems. 2010;13:949-65. doi:10.1007/s10021-010-9365-y. A fine analysis using the Biome model of how mangrove productivity may be affected by climate change. Realistic use of empirical data for some important model outcomes.

57. Saintilan N, Rogers K. Woody plant encroachment of grasslands: a comparison of terrestrial and wetland settings. New Phytol. 2014. doi:10.1111/nph.13147.

58. Ball MC, Sobrado MA. Ecophysiology of mangroves: challenges in linking physiological processes with patterns in forest structure. In: Scholes JD, Barker MG, editors. Press MC. Blackwell Oxford: Physiological plant ecology; 2002. p. 331-46.

59. Tittensor DP, Mora C, Jetz W, Lotze HK, Ricard D, Vanden Berghe E, et al. Global patterns and predictors of marine biodiversity across taxa. Nature. 2010;466:1098-101. doi:10.1038/ nature09329.

60. Comeaux RS, Allison MA, Bianchi TS. Mangrove expansion in the Gulf of Mexico with climate change: implications for wetland health and resistance to rising sea levels. Estuar Coast Shelf Sci. 2012;96:81-95. doi:10.1016/j.ecss.2011.10.003.

61. Raabe EA, Roy LC, McIvor CC. Tampa Bay coastal wetlands: nineteenth to twentieth century tidal marsh-to-mangrove conversion. Estuar Coast Shelf Sci. 2012;35:1145-62. doi:10.1007/ s12237-012-9503-1.

62. Bianchi TS, Allison MA, Zhao J, Li X, Comeaux RS, Feagin RA, et al. Historical reconstruction of mangrove expansion in the Gulf of Mexico: linking climate change with carbon sequestration in coastal wetlands. Estuar Coast Shelf Sci. 2013;119:7-16. doi:10. 1016/j.ecss.2012.12.007.

63. Osland MJ, Enwright N, Day RH, Doyle TW. Winter climate change and coastal wetland foundation species: salt marshes vs. mangrove forests in the southeastern United States. Glob Chang Biol. 2013;19:482-1494. doi:10.1111/gcb.12126. A thorough analysis of vegetation changes in the southern US as a result of climate change.

64. Stokes DJ, Healy TR, Cooke PJ. Expansion dynamics of monospecific, temperate mangroves and sedimentation in two embayments of a barrier-enclosed lagoon, Tauranga Harbour, New Zealand. J Coast Res. 2010;26:113-22. doi:10.2112/08-1043.

65. Rogers K, Saintilan N, Heijnis H. Mangrove encroachment of salt marsh in Western Port Bay, Victoria: the role of sedimentations, subsidence and sea level rise. Estuaries. 2005;28:551-9. doi:10. 1007/BP02696066.

66. Williamson GJ, Bogg GS, Bowman DMJS. Late 20th century mangrove encroachment in the coastal Australian monsoon tropics parallels the regional increase in woody biomass. Reg Environ Chang. 2011;11:19-27. doi:10.1007/s10113-010-0109-5.

67. de Boer WF. The rise and fall of the mangrove forests in Maputo Bay, Mozambique. Wetl Ecol Manag. 2002;10:313-22. doi:10. 1023/A:1020389420591.

68. Durango-Cordero JS, Satyanarayana B, Zhang J, Wang J, Chen M, Fanghong X, Chan JCW, Kanagying L, Bogaert J, Koedam N, Dahdouh-Guebas F (2013) Vegetation structure at Zhangiang Mangrove National Reserve (ZMMNR), P.R. China: a comparison between original and non-original trees using ground truthing, remote sensing and GIS techniques. http://www.vliz.be/imisdocs/ publications/232700.pdf

69. Reid PC, Beaugrand G. Global synchrony of an accelerating rise in sea surface temperature. J Mar Biol Assoc UK. 2012;92:143550. doi:10.1017/S0025315412000549.

70. Wang X, Piao S, Ciais P, Friedlingstein P, Myneni RB, Cox P, et al. A two-fold increase of carbon cycle sensitivity to tropical temperature variations. Nature. 2014. doi:10.1038/nature12915.

71. Quisthoudt K, Schmitz N, Randin CF, Dahdouh-Guebas F, Robert EMR, Koedam N. Temperature variation among mangrove latitudinal range limits worldwide. Trees. 2012;26:1919-31. doi:10. 1007/s00468-012-0760-1.

72.• Saintilan N, Wilson NC, Rogers K, Rajkaran A, Krauss KW. Mangrove expansion and salt marsh decline at mangrove poleward limits. Glob Chang Biol. 2014;20:147-57. doi:10.1111/ gcb.12341. An excellent overview of empirical and projected expansion of mangroves polewards.

73. Cavanaugh KC, Kellner JR, Forde AJ, Gruner DS, Parker JD, Rodriguez W, et al. Poleward expansion of mangroves is a threshold response to decreased frequency of extreme cold events. Proc Natl Acad Sci USA. 2014;111:723-7. doi:10.1073/pnas. 1315800111. A clear and convincing analysis of how the decline of extreme winter climate is the key to understanding the trigger for mangrove expansion.

74. Giri CP, Long JB. Mangrove reemergence in the northernmost range limit of eastern Florida. Proc Natl Acad Sci USA. 2014;111:E1447-8. doi:10.1073/pnas.1400687111.

75. Guo H, Zhang Y, Lan Z, Pennings SC. Biotic interactions mediate the expansion of black mangrove (Avicennia germinans) into salt marshes under climate change. Glob Chang Biol. 2013;19:276574. doi:10.1111/gcb.12221.

76. Proffitt CE, Travis S. Red mangrove life history variables along latitudinal and anthropogenic stress gradients. Ecol Evol. 2014. doi:10.1002/ece3.1095.

77. Bennett WA. Extreme physiology of intertidal fishes of the Wakatobi. In: Clifton J, Unsworth RKF, Smith DJ, editors. Marine research and conservation in the Coral Triangle: the Wakatobi National Park. NY: Nova; 2010. p. 111-28. 
78. Chapperon C, Seuront L. Behavioral thermoregulation in a tropical gastropod: links to climate change scenarios. Glob Chang Biol. 2011;17:1740-9. doi:10.1111/j.1365.2486.2010.02356.x.

79. Eme J, Dabruzzi TF, Bennett WA. Thermal responses of juvenile squaretail mullet (Liza vaigiensis) and juvenile crescent terapon (Teraton jarbua) acclimated at near-lethal temperatures, and the implications for climate change. J Exp Mar Biol Ecol. 2011;399: 35-8. doi:10.1016/j.jembe.2011.01.009.

80. Lai CH, Morley SA, Tan KS, Peck LS. Thermal niche separation in two sympatric tropical intertidal Laternula (Bivalvia: Anomalodesmata). J Exp Mar Biol Ecol. 2011;405:68-72. doi: 10.1016/j.jembe.2011.05.014

81. Nguyen KDT, Morley SA, Lai C-H, Clark MS, Tan KS. Upper temperature limits of tropical marine ectotherms: global warming implications. PloS ONE. 2011;6:e29340. doi:10.1371/journal. pone.0029340. An important summary of the thermal thresholds of tropical marine biota including fauna that inhabit mangroves.

82. Duke NC, Ball MC, Ellison JC. Factors influencing biodiversity and distributional gradients in mangroves. Glob Ecol Biogeogr Lett. 1998;7:27-47. doi:10.1111/j.14668238.1998.00269.x.

83. Daidu F, Congxian L. Complexities of China's coast in response to climate change. Adv Clim Chang Res. 2006;2(1):54-8.

84.•• Record S, Charney ND, Zakaria RM, Ellison AM. Projecting global mangrove species and community distributions under climate change. Ecosphere. 2013;4:34. doi:10.1890/ES12-00296.1. A fine modeling study projecting mangrove species and community responses to climate change. Offers a global view, but it is also an excellent example of how empirical data can be used to make forecasts.

85.• Polidoro BA, Carpenter KE, Collins L, et al. The loss of species: mangrove extinction risk and geographic areas of global concern. PloS ONE. 2013;5:e10095. doi:10.1371/journal.pone.0010095. An clear global view of alarming predictions of the decline of mangrove species. A wakeup call for action.

86. Collins M, Knutti R, Arblaster J, Dufresne J-L, Fichefet T, Friedlingstein P, Gao X, Gutowski T, Johns T, Krinner G, Shongwe M, Tebaldi C, Weaver AJ, Wehner M (2013) Longterm climate change: projections, commitments and irreversibility. In: Stocker TF, Qin D, Plattner G-K, Tignor M, Allen SK, Boschung J, Nauels A, Xia Y, Bex V, Midgley PM (eds.) Climate change 2013: the physical basis, contribution of working group I to the fifth assessment report of the Intergovernmental panel on climate change. Cambridge, pp 1029-1136

87. Carter RM, Johnson DP, Hooper KG. Episodic post-glacial sea-level rise and the sedimentary evolution of a tropical continental embayment (Cleveland Bay, Great Barrier Reef shelf, Australia). Aust J Earth Sci. 1993;40:229-55. doi:10.1080/08120099308728077.

88. Callaway JC, DeLaune RD, Patrick Jr WH. Sediment accretion rates from four coastal wetlands along the Gulf of Mexico. J Coast Res. 1997;13:181-91.
89. Stanley DJ, Hait AK. Holocene depositional patterns, neotectonics and Sundaban mangroves in the western Ganges-Brahmaputra Delta. J Coast Res. 2000;16:26-39.

90. Anthony EJ. Sediment dynamics and morphological stability of estuarine mangrove swamps in Sherbro Bay, West Africa. Mar Geol. 2004;208:207-24. doi:10.1016/j.margeo.2004.04.009.

91. Gonneea ME, Paytan A, Herrera-Silveira JA. Tracing organic matter sources and carbon burial in mangrove sediments over the past 160 years. Estuar Coast Shelf Sci. 2004;61:211-27. doi:10.1016/j. ecss.2004.04.015.

92. Rogers K, Saintilan N, Cahoon DR. Surface elevation changes in a regenerating mangrove forest at Homebush Bay, Australia. Wetl Ecol Manag. 2005;13:87-598. doi:10. 1007/s11273-004-0003-3.

93. Sanders CJ, Smoak JM, Sathy Naidu A, Patchineelam SR. Recent sediment accumulation in a mangrove forest and its relevance to local sea-level rise (Ilha Grande, Brazil). J Coast Res. 2008;24: 533-6. doi:10.2112/07-0872.1.

94. Sanders CJ, Smoak JM, Sanders LM, Naidu AS, Patchineelam SR. Organic carbon accumulation in Brazilian mangal sediments. J S Am Earth Sci. 2010;30:189-92. doi:10.1016/j.jsames.2010. 10.001 .

95. Sanders CJ, Smoak JM, Sathy Naidu A, Araripe DR, Sanders LM, Patchineelam SR. Mangrove forest sedimentation and its reference to sea level rise, Cananeia, Brazil. Earth Environ Sci. 2010;60: 1291-301. doi:10.1007/s12665-009-0269-0.

96. Sanders CJ, Smoak JM, Sathy Naidu A, Sanders LM, Patchineelam SR. Organic carbon burial in a mangrove forest, margin and intertidal mud flat. Estuar Coast Shelf Sci. 2010;90: 168-72.

97. Ranjan RK, Routh J, Ramanathan AL, Val Klump J. Elemental and stable isotope records or organic matter input and its fate in the Pichavaram mangrove-estuarine sediments (Tamil Nadu, India). Mar Chem. 2011;126:163-72. doi:10.1016/j.marchem.2011.05.005.

98. Ruiz-Fernández AC, Marrugo-Negrete JL, Paternina-Uribe R, Pérez-Bernal LH. ${ }^{210} \mathrm{~Pb}$-derived sedimentation rates and $\mathrm{C}_{\text {org }}$ fluxes in Soledad Lagoon (Cispatá Lagoon System, NW Caribbean Coast of Colombia). Estuar Coast Shelf Sci. 2011;34: 1117-28. doi:10.1007/s12237-011-9394-6.

99. Banderjee K, Senthilkumar B, Purvaja R, Ramesh R. Sedimentation and trace metal distribution in selected locations of Sundarbans mangroves and Hooghly estuary, Northeast coast of India. Environ Geochem Health. 2012;34:27-42. doi:10.1007/ s10653-011-9388-0.

100. Lovelock CE, Adame MF, Bennion V, Hayes M, O'Mara J, Reef $\mathrm{R}$, et al. Contemporary rates of carbon sequestration through vertical accretion of sediments in mangrove forests and saltmarshes of South East Queensland, Australia. Estuar Coast Shelf Sci. 2014;37:763-71. doi:10.1007/s12237-013-9702-4. 